\title{
Physicochemical Characterization of Natural Fibers Obtained from Seed Pods of Ceiba aesculifolia
}

\author{
Ulises Carranza-Nuñez, ${ }^{\mathrm{a}}$ Salomon Ramiro Vasquez-Garcia, ${ }^{\mathrm{a}, *}$ Nelly Flores-Ramirez, ${ }^{\mathrm{b}}$ \\ Hamdy Ahmed Abdel-Gawwad, ${ }^{\mathrm{c}}$ José Luis Rico, ${ }^{\mathrm{a}}$ Arlette Arizbe Santiago, ${ }^{\mathrm{d}}$ Joel Vargas, \\ and José Cruz-de-León ${ }^{\mathrm{b}}$ \\ Characterization of Ceiba aesculifolia (CA) fibers by various techniques is \\ herein reported. The seed pods were collected, and the fibers surrounding \\ the seeds were characterized or treated in an oven at $100{ }^{\circ} \mathrm{C}$ prior to \\ characterization by scanning electron microscopy (SEM), Fourier \\ transform infrared spectroscopy (FTIR), X-ray diffraction (XRD), and \\ thermogravimetric analysis coupled with a differential scanning \\ calorimeter (TGA-DSC). The SEM micrographs showed that the natural \\ material is comprised of tubes of external diameter of approximately 27 \\ $\mu \mathrm{m}$ and a mean wall thickness of about $0.62 \mu \mathrm{m}$. The results also indicated \\ that the tubes begin to decompose at approximately $220^{\circ} \mathrm{C}$.
}

Keywords: Ceiba aesculifolia; SEM; FTIR; DRX; TGA-DSC

Contact information: a: Department of Chemical Engineering, Universidad Michoacana de San Nicolás de Hidalgo, Morelia, 58030, México; b: Department of Wood Engineering and Technology, Universidad Michoacana de San Nicolás de Hidalgo, Morelia, 58030, México; c: Raw Building Materials Technology and Processing Research Institute, Housing and Building National Research Center (HBRC), Cairo, Egypt; d: Escuela Nacional de Estudios Superiores, Unidad Morelia, Universidad Nacional Autónoma de México, Morelia, 58190, México; e: 4 Instituto de Investigaciones en Materiales, Universidad Nacional Autónoma de México, Morelia, 58190, México; *Corresponding author: salomon_vg@yahoo.com

\section{INTRODUCTION}

Natural fibers obtained from plants and animals are used in many applications. In nature, vegetal fibers commonly contribute to the stability of the plant, or they can serve as a protection in the case of animal fibers. The world natural fiber production was approximately 33 million tons in 2013 . Among this $78.8 \%$ was cotton linter, $10 \%$ of jute, $3.6 \%$ of clean wool, $2.7 \%$ of coir, and $4.8 \%$ of other fibers such as hemp, kapok, abaca, flax, silk, ramie, and sisal (Townsend and Sette 2016). This information clearly shows the importance of vegetal fibers. These fibers may present interesting properties, for instance, high tensile and low bending and torsional rigidities. In addition, vegetal fibers with low density, are unexpansive, biodegradable, non-toxic, and easy to handle (Wambua et al. 2003; Cheung et al. 2009; Dittenber and GangaRao 2012). Due to these properties, vegetal fibers are used in many applications including housing, clothing, and packing. One recent and growing application of vegetal fibers is in the production of composites, for instance as a reinforcement of synthetic polymeric materials (Wambua et al. 2003; Cheung et al. 2009; Zakikhani et al. 2014; Djafari Petroudy 2017). Synthetic fibers present excellent mechanical properties that can be tuned according to the final application. However, these materials frequently possess ecological problems during disposal, due to their high stability under atmospheric and environmental conditions. Characterization of several vegetal fibers has been reported in the last decades (Zeriahene et al. 1998; Fiore et al. 2014; Reddy et al. 
2014; Belouadah et al. 2015; Porras et al. 2015; Mohamad et al. 2017), in addition to the well-documented cotton. Ceiba aesculifolia (CA) is a neotropical species that belongs to the Mavales order, and to the Bombacaceae family; it is distributed from Mexico to Costa Rica (Cascante-Marín 1997; Herrerías-Diego et al. 2008). This tree gives beautiful flowers and can reach $15 \mathrm{~m}$ high. The thin trunk is protected with strong thorns. The ellipsoid fruits have seed pods of about $15 \mathrm{~cm}$ long and $8 \mathrm{~cm}$ wide that keep the seeds covered with abundant soft and white fibers (Carranza-González and Blanco-García 2000; Avendaño et al. 2006). These fibers are commonly used to make pillows, and the bark, stem, and branches are used as firewood (Carranza-González and Blanco-García 2000). The number of pods that a Ceiba aesculifolia can produce every season vary according to the age of the tree and the environmental conditions. A tree can give tens or hundreds of pods. The relative abundance of this tree in our region, the basic usage of its constituents and the scarce publications related to this tree motivated the present research interest. Furthermore, the white fibers of this tree resemble those of cotton buds, and their characterization was performed for the first time in the present study. The results will undoubtedly set the basis to allow envisage new possible applications of these fibers.

\section{EXPERIMENTAL}

\section{Fibers from Ceiba aesculifolia}

Figure 1 shows an open brown CA pod, which contains a husk, fibers, and seeds. As can be observed, the fibers resemble those of the raw cotton. Their color is bright white and the texture is smooth.

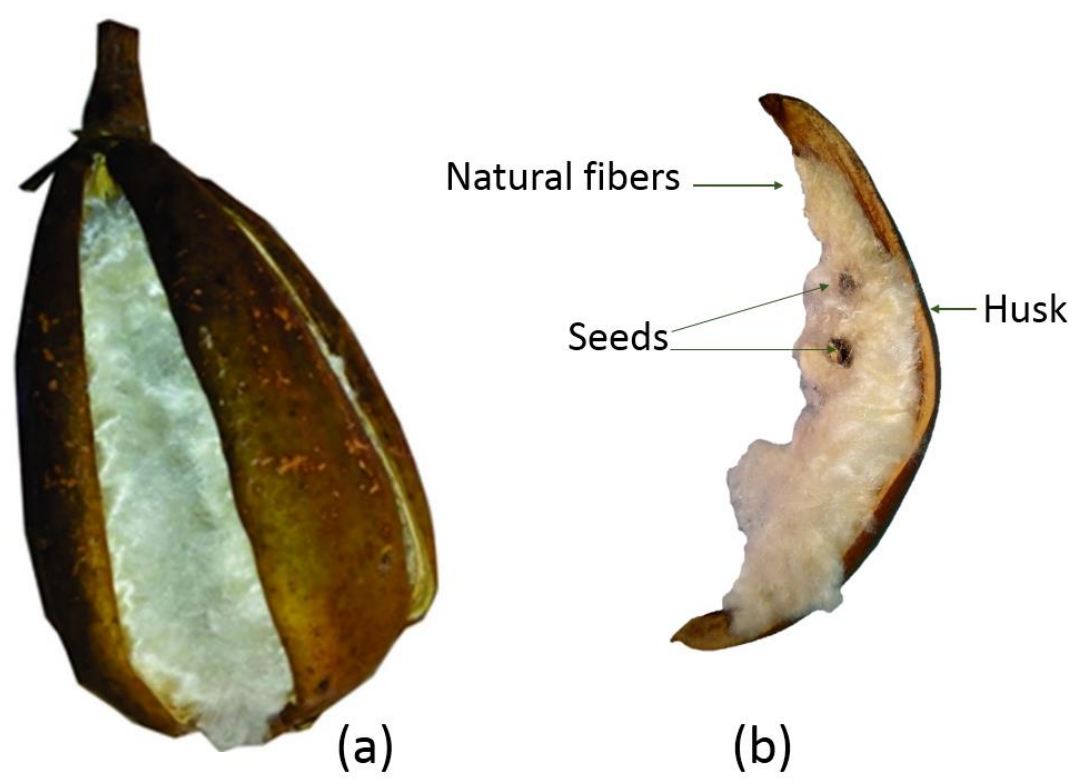

Fig. 1. Ceiba aesculifolia pod (a) and white natural fibers around the seeds (b)

The bunches of fibers used in the present study were collected after drying 10 pods under shade for a couple of months. Separation of seeds, husk, and fibers was performed. From these pods, 4.3, 8.3, and $87.4 \mathrm{wt} \%$ were determined for fibers, seeds, and husks, respectively. The results are in the range of those reported by Velázquez-Rosas et al. 
(2017). The fibers were then collected and kept for further characterization. Some were directly characterized, labelled as natural fibers (NF), or were washed with deionized water prior to further characterization. The washed fibers were denoted as WF.

\section{Characterization}

The aim of washing the fibers with deionized water was to remove some extractives and alkali metals from this material (Benítez-Guerrero et al. 2014; Rocha et al. 2017; He et al. 2018). By treating the fibers under dissimilar procedures, differences in fiber features were expected. A scanning electron microscope (SEM) (JSM-7600F, JEOL Ltd., Tokyo, Japan) provided with an energy dispersive X-ray spectrometer (EDS) was used to find fiber morphology and composition. To determine the mean diameter and wall thickness, 20 fibers were observed under the microscope. The FTIR spectra of the previously ground fibers were acquired directly with no $\mathrm{KBr}$. The equipment used for this purpose was a Perkin Elmer Spectrum 400 (Waltham, MA, USA) provided with an attenuated total reflectance (ATR) accessory. Data were acquired in 64 scans with a resolution of $4 \mathrm{~cm}^{-1}$ in the range of 650 to $4000 \mathrm{~cm}^{-1}$ with a germanium crystal. The thermal stability of the fibers was evaluated in a thermal gravimetric analyzer (TGA)-differential scanning calorimeter (DSC) device (STA 449 F3 Jupiter; Netzsch, Selb, Germany). In a typical experiment, 6 $\mathrm{mg}$ of natural fibers was collocated into an aluminum crucible and placed into the TGA chamber to be treated under nitrogen flow from ambient temperature to $600{ }^{\circ} \mathrm{C}$ at a heating rate of $5^{\circ} \mathrm{C} / \mathrm{min}$.

\section{RESULTS AND DISCUSSIONS}

\section{Natural and washed Fibers}

The following figure shows photographs of Ceiba aesculifolia.
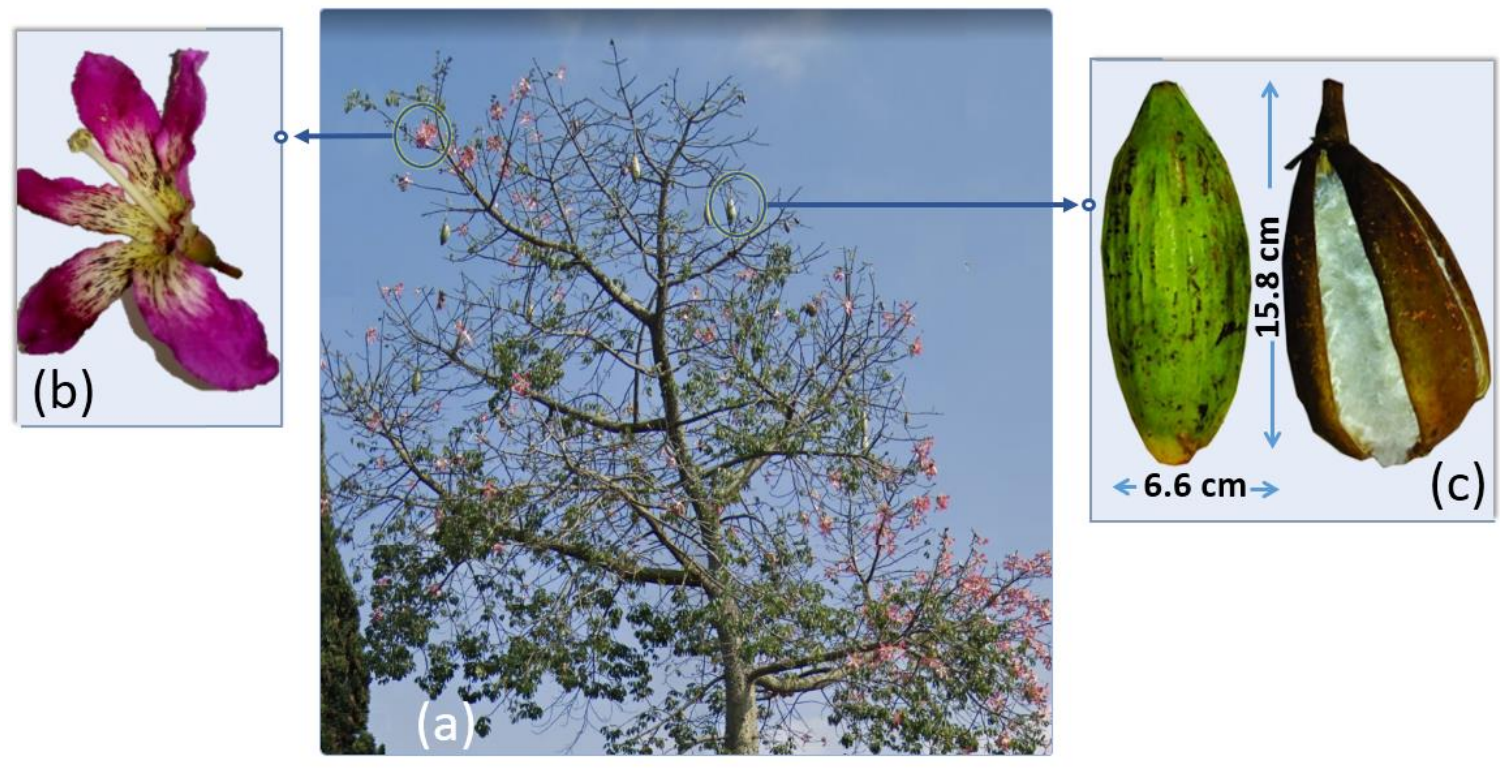

Fig. 2. Photographs of Ceiba aesculifolia: tree (a), flower (b), and pods (c) 
Figure 3 presents images of the NF and WF obtained by SEM. No apparent differences were observed. These figures show that the fibers present in the pods of this tree are indeed comprised of tubes of centimeters in length. A mean diameter of $c a .27 \mu \mathrm{m}$ and a wall thickness of $c a .0 .62 \mu \mathrm{m}$ were calculated after analyzing various SEM images.
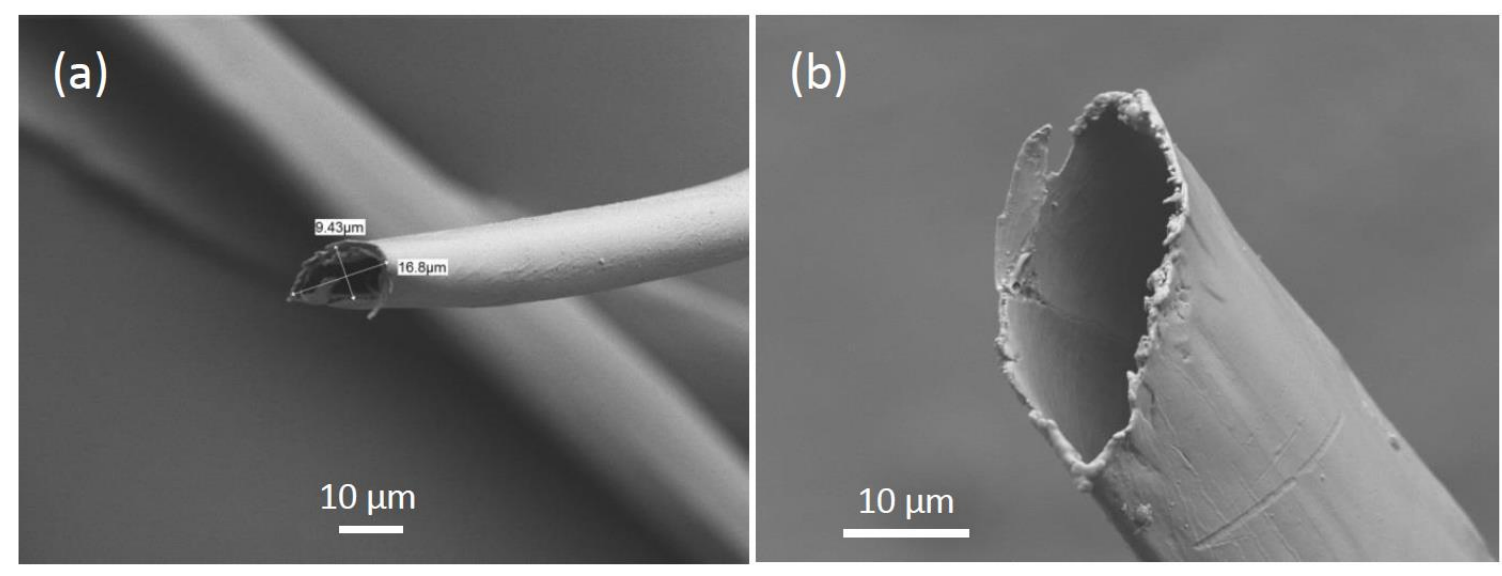

Fig. 3. SEM images of the natural tubes found in pods of the CA tree at two magnifications: 1000X (a) and 2000X (b)

\section{FTIR}

It is expected that the development of the fibers of the CA pods follows various stages, as those for cotton fibers. For the latter fibers, the overlapping stages are differentiation, initiation, polar elongation, secondary cell wall development, and maturation. The FTIR spectra for cotton wool at different periods were measured and showed that vibration positions shift slightly during biogenesis (Nelson and Mares 1965; Sathishkumar et al. 2013). Figure 4 shows the FTIR spectra of the NF and WF.

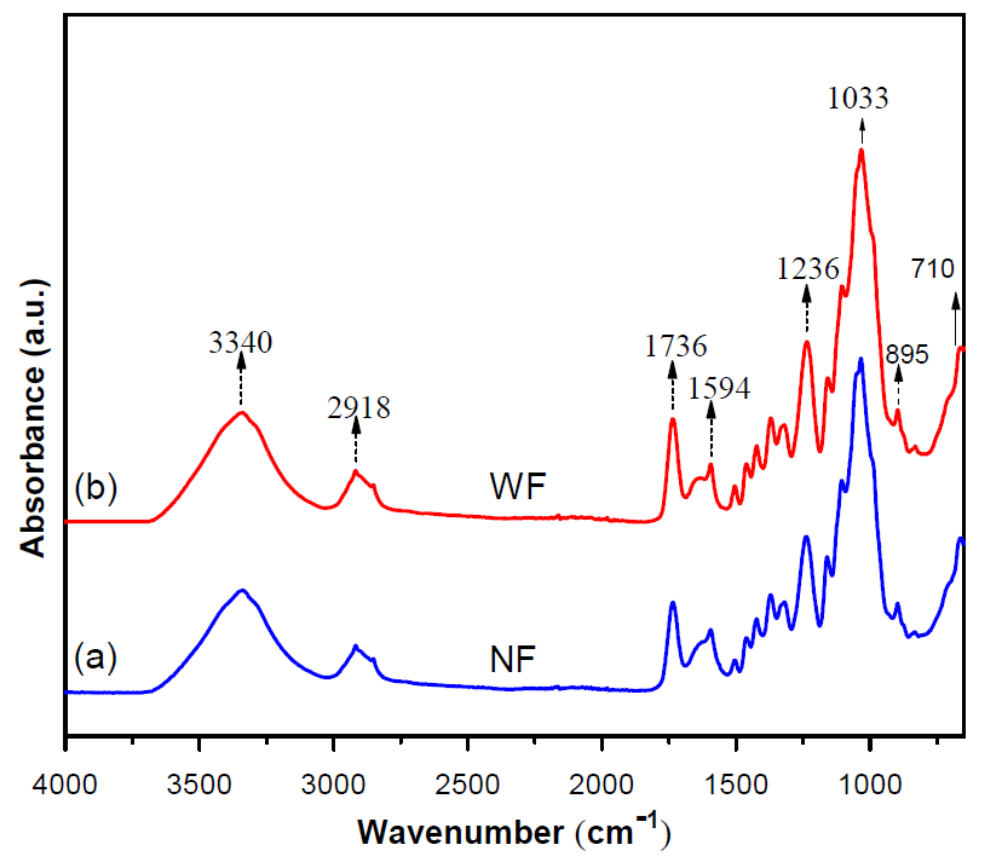

Fig. 4. FTIR spectra of the natural (a) and washed fibers (b) 
The FTIR spectra show that fibers of the CA pods are typically composed of cellulosic material, such as those reported for cotton by Abidi et al. (2014) and for Lygeum spartum L. fibers reported by Belouadah et al. (2015). Both spectra in Fig. 4 look similar, suggesting that washing was unnecessary. However, other physical properties which were not measured, such as tensile strength and bending, might be changed by this treatment. The broad band with a maximum at $3340 \mathrm{~cm}^{-1}$ was attributed to $-\mathrm{OH}$ stretching vibrations resulting from hydrogen bonding in cellulose, whereas those at approximately 2918 and $2850 \mathrm{~cm}^{-1}$ that are overlapped, were assigned to $-\mathrm{CH}_{2}$ asymmetrical and symmetrical stretching, respectively (Nelson et al. 1965) and could result from the presence of wax substances on the surface of the primary cell wall (Abidi et al. 2008). The peaks at approximately 1736,1640 , and $1594 \mathrm{~cm}^{-1}$ are attributed to $\mathrm{C}=\mathrm{O}$ stretching of lignin and hemicellulose (Sathishkumar et al. 2013), while that at approximately $1594 \mathrm{~cm}^{-1}$ is assigned to the $\mathrm{C}=\mathrm{C}$ groups of lignin (De Rosa et al. 2011). The signal at $1236 \mathrm{~cm}^{-1}$ was attributed to -COO groups of cellulose (Reddy et al. 2014). The peak at $1033 \mathrm{~cm}^{-1}$ is attributed to the stretching mode of C-O of cellulose (Ilharco et al. 1997); the signal located at $1157 \mathrm{~cm}^{-1}$ is assigned to the stretching vibration of bridge $\mathrm{C}-\mathrm{O}-\mathrm{C}$ of cellulose and hemicellulose (De Rosa et al. 2011), whereas that at $1104 \mathrm{~cm}^{-1}$ is due to anti-symmetric inplane ring stretching band (Ilharco et al. 1997). The vibration at $1236 \mathrm{~cm}^{-1}$ is attributed to $\mathrm{C}=\mathrm{O}$ stretching or $\mathrm{NH}_{2}$ deformation (Nelson et al. 1965). The peak at approximately 895 $\mathrm{cm}^{-1}$ is assigned to the $\beta$-linkage (Alonso-Simón et al. 2011). The vibration located at 710 $\mathrm{cm}^{-1}$ is attributed to $\mathrm{CH}_{2}$ rocking vibration in cellulose $\mathrm{I}_{\beta}$ (Akerholm et al. 2004), which is also characteristic of the cellulose in native cotton (Abidi et al. 2014).

\section{Thermogravimetric Analysis}

The thermal stability of the fibers obtained from the pods of the CA tree was evaluated using TGA-DTG equipment. The profile for WF was similar to that for NF and it is not shown. Figure 5 displays the thermogravimetric profile of NF.

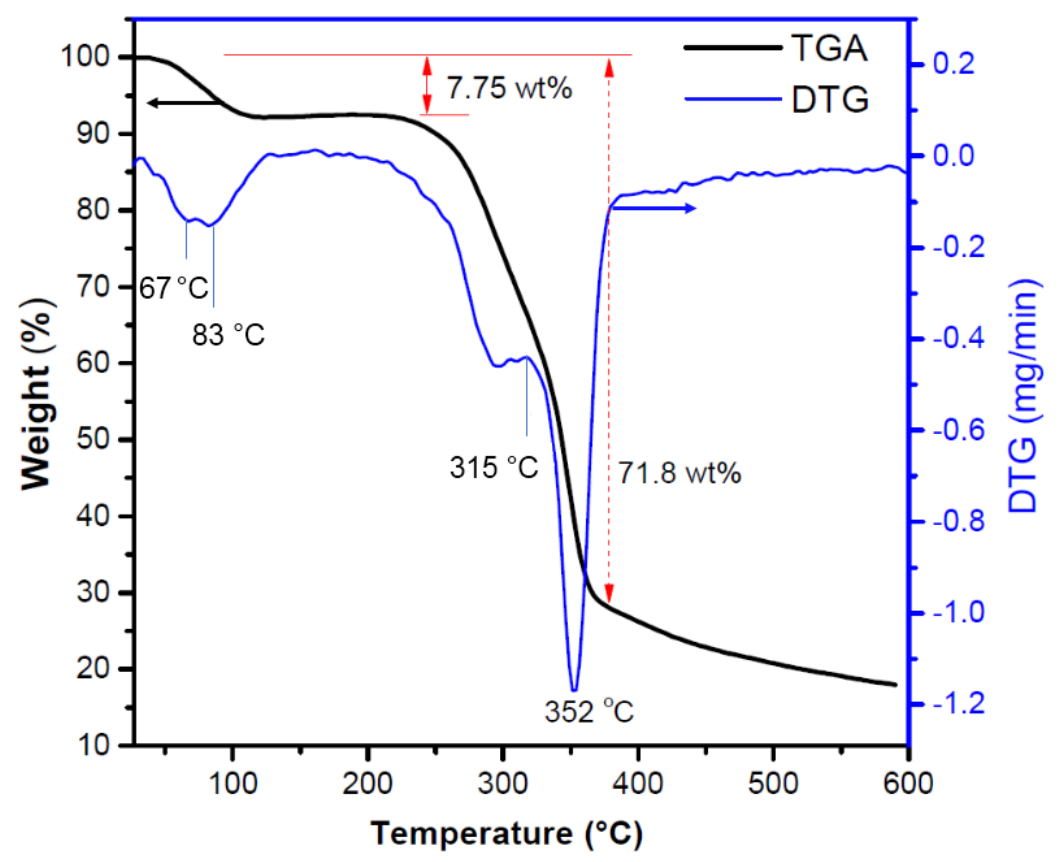

Fig. 5. TGA-DTG profiles of the NF from the pods of the CA tree 
Three main zones of weight reduction were observed in this figure. The first was related to the release of physisorbed water and occurred at temperature below $125{ }^{\circ} \mathrm{C}$ with a total weight decrease of $7.75 \mathrm{wt} \%$. The second weight decrease can be divided into two steps; one took place from approximately 210 to $315^{\circ} \mathrm{C}$ and is assigned to the elimination of hemicellulose, and the glycosidic bonds of cellulose (Indran et al. 2014). The other occurred from 315 to $377{ }^{\circ} \mathrm{C}$ and is ascribed to cellulose I and $\alpha$-cellulose (Fiore et al. 2014). The latter step exhibited the highest reduction rate of the whole thermal treatment. The total reduction in the second zone was $63.1 \mathrm{wt} \%$. The third zone of weight reduction was observed above $377{ }^{\circ} \mathrm{C}$ and is attributed to the decomposition of lignin. The total reduction in the entire thermal treatment was $82.25 \mathrm{wt} \%$. The results are in agreement with previous research studies (Broido 1969; Seki et al. 2013; Belouadah et al. 2015; Mohamad et al. 2017). Seki et al. (2013) reported for the thermal decomposition of Ferula communis fibers that cellulose decomposes in the temperature range of 240 to $350{ }^{\circ} \mathrm{C}$, hemicellulose from 200 to $260{ }^{\circ} \mathrm{C}$, and lignin from 280 to $500{ }^{\circ} \mathrm{C}$. In the research work published by Belouadah et al. (2015) and Mohamad et al. (2017), the authors reported a similar thermogravimetric profile for the cellulosic fiber from Lygeum spartum which is in agreement to ours in the present study.

With the aim to obtain the apparent activation energy, the method reported by Broido (1969) and Saravanakumar et al. (2013) was followed. To this purpose, the TGADSC results were used and plotted using the following equation,

$$
\ln \left[\ln \left(\frac{1}{y}\right)\right]=-\frac{E}{R}\left[\left(\frac{1}{T}+K\right)\right]
$$

where $R$ is the ideal gas constant, $K$ is a constant, $E$ is the apparent activation energy (KJ/mol), $T$ is the absolute temperature (Kelvin), and $y$ is the normalized weight, defined as $w_{0} / w$, being $w_{0}$ the initial sample weight $(\mathrm{g})$ and $w$ the weight $(\mathrm{g})$ at any time. When plotting the experimental data using the above equation, a straight line with correlation coefficient of 0.9998 was obtained. From the graph, the apparent activation energy of 96.8 $\mathrm{kJ} / \mathrm{mol}$ was calculated. It is worth commenting that activation energies for other natural materials are in the range 60 to $170 \mathrm{~kJ} / \mathrm{mol}$ (Yao et al. 2008; Saravanakumar et al. 2013; Indran et al. 2014; Belouadah et al. 2015). Indran et al. (2014) reported an apparent activation energy of $74.2 \mathrm{~kJ} / \mathrm{mol}$ for $C$. quadrangularis natural fibers; Saravanakumar et al. (2013a) of $76.7 \mathrm{~kJ} / \mathrm{mol}$ for P. juliflora natural fibres; Belouadah et al. (2015) of 68.8 $\mathrm{kJ} / \mathrm{mol}$ for Lygeum spartum L. natural fibers, and Yao et al. (2008) reported values of 160$170 \mathrm{~kJ} / \mathrm{mol}$ for wood, bamboo, agricultural residue, and bast fibers. Table 1 exhibits additional values reported for other fibers.

\section{X-Ray Diffraction}

Native cellulose is believed to possess only a unique structure, called cellulose I. However, it was proposed that it consists of two crystalline allomorphs, $I_{\alpha}$ and $I_{\beta}$ (Atalla and VanderHart 1984). According to literature, cellulose $\mathrm{I}_{\alpha}$ presents a triclinic one-chain unit cell $\left(\mathrm{a}=6.717 \AA, \mathrm{b}=5.962 \AA, \mathrm{c}=10.400 \AA, \alpha=118.08^{\circ}, \beta=114.80^{\circ}\right.$, and $\left.\gamma=80.37^{\circ}\right)$ (Sugiyama et al. 1991) with parallel cellulose chains that are piled up by Van der Waals interactions. In addition, the structure shows a progressive shear along the chain axis. Cellulose $\mathrm{I}_{\beta}$ presents a monoclinic two-chain unit cell $(\mathrm{a}=7.784 \AA$, $\mathrm{b}=8.201 \AA$, $\mathrm{c}=10.38$ $\AA, \alpha=\beta=90^{\circ}$, and $\gamma=96.5^{\circ}$ ) (Nishiyama et al. 2002) with stacking of parallel chains and alternating shear (Sugiyama et al. 1991). Furthermore, cellulose $\mathrm{I}_{\alpha}$ can be transformed into cellulose $\mathrm{I}_{\beta}$ by hydrothermal treatment or with solvents following various treatments 
(Debzi et al. 1991). The X-ray diffraction pattern of the fibers around the seeds of the CA tree is presented in Fig. 6, which is characteristic of cellulosic materials. Since the XRD pattern for WF was similar to that for NF, it is not shown. The main reflections occurred at approximately $14.0,22.0$, and $34.5^{\circ}(2 \theta)$. The assigning of reflections to crystal planes of a natural material was not straightforward due to the presence of cellulose, hemicellulose, and lignin. The broad reflection at approximately $14^{\circ} 2 \theta$ was composed of overlapped signals, for instance, the peaks at approximately $10.5,14.7$, and $16.9^{\circ} 2 \theta$ were assigned to the Miller indexes of (001), (100), and (010) of cellulose $\mathrm{I}_{\alpha}$, and those at approximately $14.9,16.8^{\circ} 2 \theta$ for (1-10) and (110) planes of cellulose $\mathrm{I}_{\beta}$, could well be fitted within this region. Similarly, for reflections at 22 and $34.2^{\circ} 2 \theta$. Both phases may therefore be present in the material; however, more characterization would be needed to elucidate this. It has been reported that cellulose $\mathrm{I}_{\beta}$ is dominant in higher plants, whereas cellulose $\mathrm{I}_{\alpha}$ phase was only found in algal and bacterial cellulose (Igarashi et al. 2007; Habibi et al. 2010). However, Atalla and VanderHart (1984) found several anomalies in the nuclear magnetic resonance (NMR) spectra of celluloses from vascular plants, algae, bacteria, and tunicates, which seem to indicate that vascular plants may contain only cellulose $\mathrm{I}_{\beta}$. Figure 6 shows the XRD pattern of the NF from the pods of CA tree and the reflections of the cellulose $I_{\beta}$ phase as a reference (French 2014).

Following the method reported by Segal et al. (1959), the index of crystallinity can be calculated by taking the heights of the intensity of the reflection at approximately $22^{\circ}$ $2 \theta$ and that of the amorphous at approximately $18^{\circ} 2 \theta$. The calculated index of crystallinity was 0.63 . The higher this value the greater the fiber resistance to bacteria, thermal, and chemical treatments (Ma et al. 2012; Lu et al. 2016; Mohamad et al. 2017).

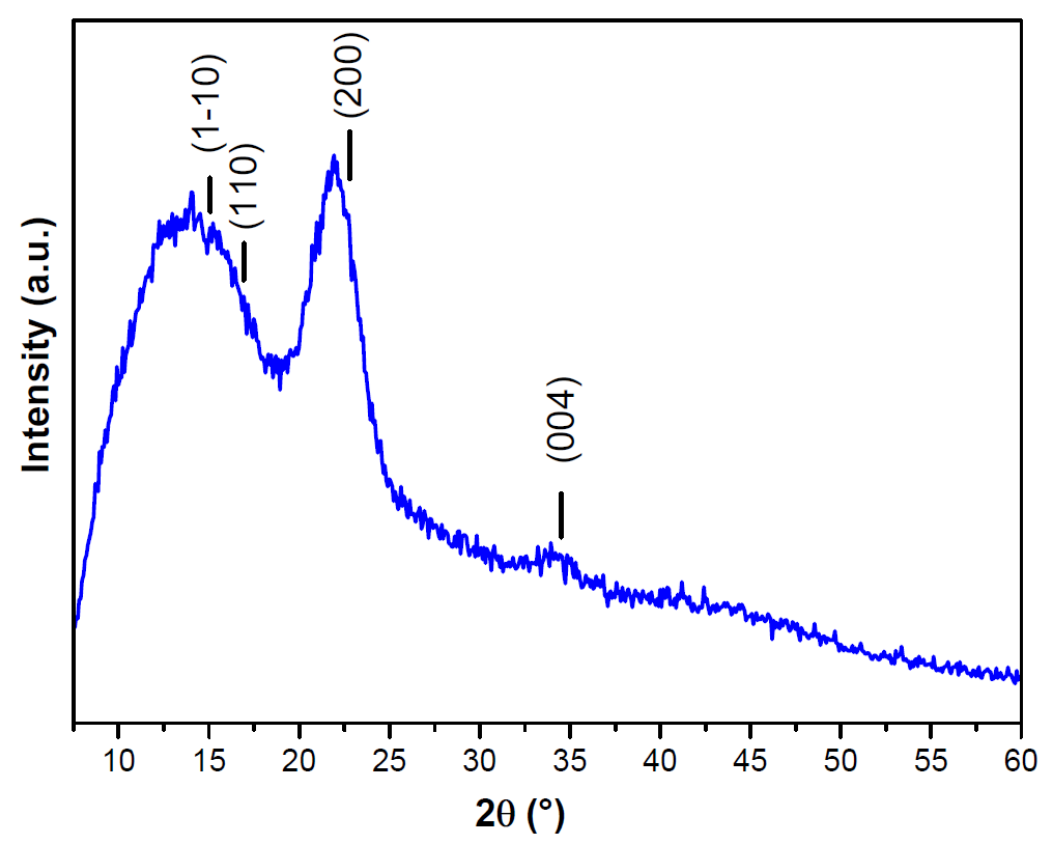

Fig. 6. The XRD pattern of the natural fibers surrounding the seeds of the CA tree and planes of reference for cellulose ${ }_{\beta}$

Table 1 summarizes some properties of the fibers of the CA tree determined in the present study and compares the values to those of other fibers reported in the literature. 
Table 1. Characterization of the Fibers Covering the Seeds of the CA Tree Compared to Other Cellulose Fibers

\begin{tabular}{|c|c|c|c|c|}
\hline Fibers & $\begin{array}{l}\text { Mean fiber } \\
\text { diameter } \\
(\mu \mathrm{m})\end{array}$ & $\begin{array}{l}\text { Mean wall } \\
\text { thickness } \\
(\mu \mathrm{m})\end{array}$ & $\begin{array}{c}\text { Apparent activation } \\
\text { energy }(\mathrm{kJ} / \mathrm{mol})\end{array}$ & $\begin{array}{l}\text { Crystallinity } \\
\text { index (\%) }\end{array}$ \\
\hline Cotton (neat) & $16.8^{a}$ & 3.9 & $178^{b}$ & $0.64^{c}$ \\
\hline CA-present study & 27 & 0.62 & 96.85 & 63 \\
\hline Eucalyptus wood & 13.28 & 3.0 & 184.9 to $229.7^{i}$ & $68^{e}$ \\
\hline Flax & $19^{e}$ & $10^{e}$ & $76.64^{\mathrm{h}}$ & 50 to $90^{e}$ \\
\hline Pine (softwood) & 20 to $40^{d}$ & 8 to $11^{\mathrm{e}}$ & $161.5^{f}$ & 52 to $62^{e}$ \\
\hline Hemp & $25^{\mathrm{e}}$ & $10^{e}$ & $180.9^{f}$ & 50 to $90^{e}$ \\
\hline Jute & $20^{e}$ & $5.2^{\mathrm{d}}$ & $183.1^{f}$ & $71^{g}$ \\
\hline Bamboo & $14^{\mathrm{e}}$ & $7^{e}$ & $164.1^{f}$ & $45.33^{9}$ \\
\hline
\end{tabular}

\section{CONCLUSIONS}

1. The characterization of the fibers covering the seeds found in the seed pods of the Ceiba aesculifolia (CA) tree is herein reported. The fibers are comprised of microtubes of millimeters in length, with a mean external diameter of about $27 \mu \mathrm{m}$ and a wall thickness of $0.62 \mu \mathrm{m}$.

2. The CA tubes showed a characteristic Fourier transform infrared (FTIR) spectrum and the X-ray diffraction (XRD) pattern is similar to those reported for other cellulosic materials. The determined crystallinity index was 0.63 .

3. The thermogravimetric analysis - differential scanning calorimetry (TGA-DSC) results indicated that the tubes are resistant below $220{ }^{\circ} \mathrm{C}$, and above this temperature, the structure eventually collapsed and decomposed. Various applications of this natural source are envisaged, for instance, as an acoustic or electrical insulation, and as reinforcement of other polymeric materials. Furthermore, the tubes could be used as templates to synthetize other interesting inorganic structures, such as silica and titania, among others.

\section{ACKNOWLEDGMENTS}

The authors acknowledge the Scientific Research Council of the Universidad Michoacana de San Nicolas de Hidalgo (CIC-UMSNH) for their financial support.

\section{REFERENCES CITED}

Abidi, N., Cabrales, L., and Haigler, C. H. (2014). "Changes in the cell wall and cellulose content of developing cotton fibers investigated by FTIR spectroscopy," Carbohyd. Polym. 100, 9-16. DOI: 10.1016/j.carbpol.2013.01.074

Abidi, N., Hequet, E., Cabrales, L., Gannaway, J., Wilkins, T., and Wells, L. W. (2008). "Evaluating cell wall structure and composition of developing cotton fibers using 
Fourier transform infrared spectroscopy and thermogravimetric analysis," J. Appl. Polym. Sci. 107(1), 476-486. DOI: 10.1002/app.27100

Åkerholm, M., Hinterstoisser, B., and Salmén, L. (2004). "Characterization of the crystalline structure of cellulose using static and dynamic FT-IR spectroscopy," Carbohydr. Res. 339(3), 569-578. DOI: 10.1016/j.carres.2003.11.012

Alonso-Simón, A., García-Angulo, P., Mélida, H., Encina, A., Álvarez, J. M., and Acebes, J. L. (2011). "The use of FTIR spectroscopy to monitor modifications in plant cell wall architecture caused by cellulose biosynthesis inhibitors," Plant. Signal. Behav. 6(8), 1104-1110. DOI: 10.4161/psb.6.8.15793

Atalla, R. H., and VanderHart, D. L. (1984). "Native cellulose: A composite of two distinct crystalline forms," Science 223(4633), 283-285. DOI:

10.1126/science.223.4633.283

Avendaño, A., Casas, A., Dávila, P., and Lira, R. (2006). "Use forms, management and commercialization of "pochote" Ceiba aesculifolia (H.B. \& K.) Britten \& Baker f. subsp. parvifolia (Rose) P.E. Gibbs \& Semir (Bombacaceae) in the Tehuacán Valley, Central Mexico," J. Arid. Environ. 67(1), 15-35. DOI:

10.1016/j.jaridenv.2006.02.004

Belouadah, Z., Atib, A., and Rokbi, M. (2015). "Characterization of new natural cellulosic fiber from Lygeum spartum L.," Carbohyd. Polym. 134, 429-437. DOI: 10.1016/j.carbpol.2015.08.024

Benítez-Guerrero, M., López-Beceiro, J., Sánchez-Jiménez, P. E., and Pascual-Cospa, J. (2014). "Comparison of thermal behavior of natural and hot-washed sisal fibers based on their main components: Cellulose, xylan and lignin. TG-FTIR analysis of volatile products," Thermochim. Acta. 581, 70-86. DOI: 10.1016/j.tca.2014.02.013

Broido, A. (1969). "A simple, sensitive graphical method of treating thermogravimetric analysis data," J. Polym. Sci. A-2: Polym. Phys. 7(10), 1761-1773. DOI: 10.1002/pol.1969.160071012

Cabrales, L., and Abidi, N. (2010). "On the thermal degradation of cellulose in cotton fibers," J. Therm. Anal. Calorim. 10(2), 485-491. DOI: 10.1007/s10973-010-0911-9

Carranza-González, E., and Blanco-García, A. (2000). "Bombacaceae [Bombacaceae]," in: Flora del Bajío y de Regiones Adyacentes Fascículo 90, Instituto de Ecología, A.C. Centro Regional del Bajío (Ed), Pátzcuato, Michoacan, México, pp. 1-13.

Cascante-Marín, A. (1997). "La familia Bombacaceae (Malvales) en Costa Rica [Bombacaceae (Malvales) family in Costa Rica]," Brenesia 47-48, 17-36.

Cheung, H. Y., Ho, M. P., Lau, K. T., Cardona, F., and Hui, D. (2009). "Natural fibrereinforced composites for bioengineering and environmental engineering applications," Compos. Part B-Eng. 40(7), 655-663. DOI: 10.1016/j.compositesb.2009.04.014

De Rosa, I. M., Kenny, J. M., Maniruzzaman, M., Moniruzzaman, M., Monti, M., Puglia, D., Santulli, C., and Sarasini, F. (2011). "Effect of chemical treatments on the mechanical and thermal behaviour of okra (Abelmoschus esculentus) fibres," Compos. Sci. Technol. 71(2), 246-254. DOI: 10.1016/j.compscitech.2010.11.023

Debzi, E. M., Chanzy, H., Sugiyama, J., Tekely, P., and Excoffier, G. (1991). "The I $\alpha$ $\rightarrow \mathrm{I} \beta$ transformation of highly crystalline cellulose by annealing in various mediums," Macromolecules 24(26), 6816-6822. DOI: 10.1021/ma00026a002

Dittenber, D. B., and GangaRao, H. V. S. (2012). "Critical review of recent publications on use of natural composites in infrastructure," Compos. Part A-Appl. S. 43(8) 14191429. DOI: 10.1016/j.compositesa.2011.11.019 
Djafari Petroudy, S. R. (2017). "Physical and mechanical properties of natural fibers," in: Advanced High Strength Natural Fibre Composites in Construction. Woodhead Publishing, 59-83. DOI: /10.1016/B978-0-08-100411-1.00003-0

Fiore, V., Scalici, T., and Valenza, A. (2014). "Characterization of a new natural fiber from Arundo donax L. as potential reinforcement of polymer composites," Carbohyd. Polym. 106, 77-83. DOI: 10.1016/j.carbpol.2014.02.016

French, A. D. (2014). "Idealized powder diffraction patterns for cellulose polymorphs," Cellulose 21, 885-896. DOI: 10.1007/s10570-013-0030-4

Graham, B. P., and Haigler, C. H. (2021). "Microtubules exert early, partial, and variable control of cotton fiber diameter," Planta 253(47), 1-17. DOI: 10.1007/s00425-02003557-1

Habibi, Y., Lucia, L. A., and Rojas, O. J. (2010). "Cellulose nanocrystals: Chemistry, self-assembly, and applications," Chem. Rev. 110(6), 3479-3500. DOI:

$10.1021 / \mathrm{cr} 900339 \mathrm{w}$

He, M., Yang, G., Chen J., Ji, X., and Wang, Q. (2018). "Production and characterization of cellulose nanofibrils from different chemical and mechanical pulps," J. Wood Chem. Technol. 38(2), 149-158. DOI: 10.1080/02773813.2017.1411368

Herrerías-Diego, Y., Quesada, M., Stoner, K. E., Lobo, J. A., Hernández-Flores, Y., and Sanchez Montoya, G. S. (2008). "Effect of forest fragmentation on fruit and seed predation of the tropical dry forest tree Ceiba aesculifolia," Biol. Conserv. 141(1), 241-248. DOI: 10.1016/j.biocon.2007.09.017

Igarashi, K., Wada, M., and Samejima, M. (2007). "Activation of crystalline cellulose to cellulose IIII results in efficient hydrolysis by cellobiohydrolase," FEBS J. 274(7), 1785-1792. DOI: 10.1111/j.1742-4658.2007.05727.x

Ilharco, L. M., Garcia, A. R., Lopes da Silva, J., and Vieira Ferreira, L. F. (1997). "Infrared approach to the study of adsorption on cellulose: Influence of cellulose crystallinity on the adsorption of benzophenone," Langmuir 13(15), 4126-4132. DOI: $10.1021 / \mathrm{la962138u}$

Indran, S., Edwin Raj, R., and Sreenivasan, V. S. (2014). "Characterization of new natural cellulosic fiber from Cissus quadrangularis root," Carbohyd. Polym. 110, 423-429. DOI: 10.1016/j.carbpol.2014.04.051

Lu, Q., Cai, Z., Lin, F., Tang, L., Wang, S., and Huang, B. (2016). "Extraction of cellulose nanocrystals with a high yield of $88 \%$ by simultaneous mechanochemical activation and phosphotungstic acid hydrolysis," ACS Sustain. Chem. Eng. 4(4), 2165-2172. DOI: 10.1021/acssuschemeng.5b01620

Ma, H., Burger, C., Hsiao, B. S., and Chu, B. (2012). "Highly permeable polymer membranes containing directed channels for water purification," ACS Macro Lett. 1(6), 723-726. DOI: 10.1021/mz300163h

Mohamed, M. A., Salleh, W. N. W., Jaafar, J., Ismail, A. F., Mutalib, M. A., Mohamad, A. B., Zain, M. F. M., Awang, N. A., and Hir, Z. A. M. (2017). "Physicochemical characterization of cellulose nanocrystal and nanoporous self-assembled CNC membrane derived from Ceiba pentandra," Carbohyd. Polym. 157, 1892-1902. DOI: 10.1016/j.carbpol.2016.11.078

Monti, A., and Alexopoulou, E. (2013). Kenaf: A Multi-Purpose Crop for Several Industrial Applications. New Insights from the Biokenaf Project, Springer, Verlag London, UK.

Moshi, A. A. M., Ravindran, D., Bharathi, S. R. S., Padma, S. R., Indran, S., and Divya D. (2020). "Characterization of natural cellulosic fiber extracted from Grewia damine 
flowering plant's stem," Int. J. Biol. Macromol. 164, 1246-1255. DOI: 10.1016/j.ijbiomac.2020.07.225

Nelson, M. L., and Mares, T. (1965). "Accessibility and lateral order distribution of the cellulose in the developing cotton fiber," Text. Res. J. 35(7), 592-603. DOI: 10.1177/004051756503500703

Nishiyama, Y., Langan, P., and Chanzy, H. (2002). "Crystal structure and hydrogenbonding system in cellulose $\mathrm{I} \beta$ from synchrotron $\mathrm{X}$-ray and neutron fiber diffraction," J. Am. Chem. Soc. 124(31), 9074-9082. DOI: 10.1021/ja0257319

Poletto, M., Zattera, A. J., and Santana, R. M. C. (2012). "Thermal decomposition of wood: Kinetics and degradation mechanisms," Bioresour. Technol. 126, 7-12. DOI: 10.1016/j.biortech.2012.08.133

Porras, A., Maranon, A., and Ashcroft, I. A. (2015). "Characterization of a novel natural cellulose fabric from Manicaria saccifera palm as possible reinforcement of composite materials," Compos. Part B-Eng. 74, 66-73. DOI: 10.1016/j.compositesb.2014.12.033

Reddy, K. O., Ashok, B., Reddy, K. R. N., Feng, Y. E., Zhang, J., and Rajulu, A. V. (2014). "Extraction and characterization of novel lignocellulosic fibers from Thespesia lampas plant," Int. J. Polym. Anal. Ch. 19(1), 48-61. DOI: 10.1080/1023666X.2014.854520

Rocha, E. P. A., Sermyagina, E., Vakkilainen, E., Colodette, J. L., de Oliveira, I. M., and Cardoso, M. (2017). "Kinetics of pyrolysis of some biomasses widely available in Brazil," J. Therm. Anal. Calorim. 130(3), 1445-1454. DOI: 10.1007/s10973-0176138-2

Saravanakumar, S. S., Kumaravel, A., Nagarajan, T., Sudhakar, P., and Baskaran, R. (2013). "Characterization of a novel natural cellulosic fiber from Prosopis juliflora bark," Carbohyd. Polym. 92(2), 1928-1933. DOI: 10.1016/j.carbpol.2012.11.064

Sathishkumar, T. P., Navaneethakrishnan, P., Shankar, S., and Rajasekar, R. (2013). "Characterization of new cellulose Sansevieria ehrenbergii fibers for polymer composites," Compos. Interface. 20(8), 575-593. DOI:

10.1080/15685543.2013.816652

Segal, L., Creely, J. J., Martin, A. E., and Conrad, C. M. (1959). "An empirical method for estimating the degree of crystallinity of native cellulose using the X-ray diffractometer," Text. Res. J. 29(10), 786-794. DOI: 10.1177/004051755902901003

Seki, Y., Sarikanat, M., Sever, K., and Durmuşkahya, C. (2013). "Extraction and properties of Ferula communis (chakshir) fibers as novel reinforcement for composites materials," Compos. Part B-Eng. 44(1), 517-523. DOI: 10.1016/j.compositesb.2012.03.013

Sugiyama, J., Vuong, R., and Chanzy, H. (1991). "Electron diffraction study on the two crystalline phases occurring in native cellulose from an algal cell wall," Macromolecules 24(14), 4168-4175. DOI: 10.1021/ma00014a033

Townsend, T., and Sette, J. (2016). "Chapter: Natural fibres and the world economy," in: Advances in Science and Technology towards Industrial Applications, R. Fangueiro, and S. Rana (eds.), Springer Nature, Basel, Switzerland, pp. 381-390.

Velázquez-Rosas, N., Ruiz-Guerra, B., Sánchez-Coronado, M. E., Gamboa-de Buen, A., and Orozco-Segovia, A. (2017). "Morphological variation in fruits and seed of Ceiba aesculifolia and its relationship with germination and seedling biomass," Bot. Sci. 95(1), 1-11. DOI: 10.17129/botsci.636 
Vincent, S. S., Mahinpey, N., and Mani T. (2015). "Torrefaction of flax straw biomass and its kinetic studies," Energ. Source. Part A. 37(21), 2338-2345. DOI: 10.1080/15567036.2012.714053

Wambua, P., Ivens, J., and Verpoest, I. (2003). "Natural fibres: Can they replace glass in fibre reinforced plastics?,” Compos. Sci. Technol. 63(9), 1259-1264. DOI: 10.1016/S0266-3538(03)00096-4

Wang, M., She, Y., Xiao, Z., Hu, J., Zhou, R., and Zhang, J. (2014). “The green adsorption of chitosan tripolyphosphate nanoparticles on cotton fiber surfaces," Carbohyd. Polym. 101, 812-818. DOI: 10.1016/j.carbpol.2013.10.023

Wentze, M., Brischke, C., and Militz H. (2019). "Dynamic and static mechanical properties of Eucalyptus nitens thermally modified in an open and closed reactor system," Maderas, Cienc. Tecnol. 21(2), 141-152. DOI: 10.4067/S0718221X2019005000201

Yao, F., Wu, Q., Lei, Y., Guo, W., and Xu, Y. (2008). “Thermal decomposition kinetics of natural fibers: Activation energy with dynamic thermogravimetric analysis," Polym. Degrad. Stabil. 93(1), 90-98. DOI: 10.1016/j.polymdegradstab.2007.10.012

Zakikhani, P., Zahari, R., Sultan, M. T. H., and Majid, D. L. (2014). "Extraction and preparation of bamboo fibre-reinforced composites," Mater. Design 63, 820-828. DOI: $10.1016 /$ j.matdes.2014.06.058

Zeriahene, N., Prat, R., Goldberg, R., Catesson, A. M., and Harche-Kaid, M. (1998). "Cell walls of seed hairs from Lygeum spartum: Ultrastructure, composition and mechanical properties,” Ann. Bot. 81(1), 61-66. DOI: 10.1006/anbo.1997.0530

Article submitted: February 21, 2020; Peer review completed: June 13, 2020; Revised version received and accepted: April 2, 2021; Published: April 30, 2021.

DOI: $10.15376 /$ biores.16.2.4200-4211 